\title{
Effect of Foreign Language Anxiety on Gender and Academic Achievement among Yemeni University EFL Students
}

\author{
Norizan Abdul Razak ${ }^{1}$, Amr Abdullatif Yassin ${ }^{1,2}$ \& Tengku Nor Rizan Bt Tengku Mohamad Maasum ${ }^{1}$ \\ ${ }^{1}$ Faculty of Social Sciences and Humanities, Universiti Kebangsaan Malaysia, Bangi, Selangor, Malaysia \\ ${ }^{2}$ Centre of Languages and Translation, Ibb University, Ibb, Yemen \\ Correspondence: Amr Abdullatif Yassin, Centre of Languages and Translation, Ibb University, Yemen. Tel: \\ 60-133-378-218. E-mail: amryassin84@gmail.com
}

\author{
Received: July 25, 2016 Accepted: January 8, 2017 Online Published: January 11, 2017 \\ doi: 10.5539/elt.v10n2p73 URL: http://dx.doi.org/10.5539/elt.v10n2p73
}

\begin{abstract}
This study aimed to investigate the gender differences in terms of anxiety among Yemeni university EFL learners. It also aimed to investigate the correlation between the level of anxiety and the academic achievement of the students. The participants of this study were 155 students chosen from the population through stratified random sampling. The participants are selected from English Department, Faculty of Arts, Ibb University, Yemen. The data was collected by using a questionnaire adopted from Yassin (2015), and the data was analysed by using 22nd version of the SPSS. The data of the first question was analysed by using T-test and the result of the analysis showed that the females experienced higher level of anxiety than male students, but the difference between both groups is not significant. The second question was analysed by using Pearson Product Moment Correlation and the result showed that there is not significant correlation between the level of anxiety and the academic achievement of the students.
\end{abstract}

Keywords: foreign language anxiety, Yemeni EFL students, gender, academic achievement

\section{Introduction}

Psychological aspects of the learners have attracted the researchers due to their main role in debilitating or enhancing the process of learning a second or foreign language. Learning a second or foreign language needs additional emotional and cognitive efforts and one of the variables that have an effect on the process of learning an additional language is foreign language anxiety (Abu-Rabia, 2004). Language anxiety is one of the characteristics of learning an additional language. However, FL students experience higher level of anxiety than SL learners (Siegel, 1989). The term Foreign Language Anxiety came into existence after the work of Horwitz et al. (1986) who defined anxiety as "the feeling of tension, apprehension and nervousness associated with the situation of learning a Foreign Language". The type of anxiety experienced by the students when learning a second or foreign language is state or situational anxiety, and it is not trait anxiety because the students experience this type of anxiety when they, for example, speak inside the classroom in front of their peers and teachers. This type of anxiety is transitory and the students can overcome it with the passage of time (Spielberger, 1983; Abu-Rabia, 2004; Ezzi, 2012).

There are many factors that influence the process of learning second or foreign language, and anxiety is considered one of the most affective factors in this regard. The investigation of the effectiveness of anxiety was realized in the early of the $1970 \mathrm{~s}$ in the western countries and there are many studies that were carried out to investigate foreign language anxiety such as (Chastain, 1975; Bailey, 1983).

Among the issues which have been investigated is anxiety and its effect on gender and academic achievement and the results of the relationship between anxiety, gender and academic achievement is a controversial matter. This study will investigate the gender differences in terms of anxiety and the relationship between anxiety and academic achievement of Yemeni university EFL students.

The problem of anxiety is one of the affective factors that exist among Yemeni EFL students even those who have gained an advanced level of proficiency (Ezzi, 2012). Students experience anxiety not only inside the classroom but also outside the classroom especially when they use the language in real communicative situations (Tanveer, 2007) 
Yemeni male and female students study the primary and secondary schools in separate schools. However, in the university the education is coeducation and this creates a gender gap and might increase the level of anxiety inside the classroom (Ezzi, 2012). It is, therefore, a fertile area to investigate the gender differences in the level of foreign language anxiety among Yemeni students.

One of the problems that might be resulted from the experience of foreign language anxiety is the possible negative effect on the academic achievement of the students (Comunian, 1993; Mwamwenda, 1994).There are many studies have proved that the students who experience high level of anxiety usually have low academic achievement and vice versa; however, this is still a controversial matter as some studies did not show a correlation between the level of anxiety and the academic achievement of the learners.

\section{Review of Previous Studies}

\subsection{Foreign Language Anxiety and Gender}

There are many studies that have discussed gender and investigated the differences between males and females in terms of anxiety which the students experience when learning a foreign language. This issue is still a controversial matter as the studies gave mixed results concerning the difference between males and females in terms of anxiety. There many studies showed that female students experience higher level of anxiety than male students when studying a foreign language (Bensoussan \& Zeidner, 1989; Abu-Rabia, 2004). The study of Abu-Rabia (2004) was conducted in Israel among Jewish students who are enrolled in the seventh grade. The participants in this study are studying English which is a foreign language for the students. Both genders who participated in the study were taken from two different classes in Jewish schools. The study found that female students experience a level of anxiety higher than male students. According to the regression analysis, teachers' attitudes and gender explained about $43 \%$ of the anxiety variance and gender has the priority in anxiety prediction than the attitudes of the teachers.

Abu-Rabia (2004) argued that female students might express their feelings of anxiety because females are open and they express their feelings easily. On the other hand, male students are not open and they do not express their feelings easily so they might not reveal their feelings of experiencing anxiety in the process of learning a foreign or second language.

Aida (1994) did not find a significant foreign language classroom anxiety difference between males and females among Japanese students. Also, Shi et al. (2006) revealed that the difference between male and female Chinese EFL students is not that significant. However, the study revealed that female students experience a lower level of anxiety than males in foreign language reading anxiety. One of the reasonable explanations is that the female students experience lower level of anxiety than males because they got higher scores in English test. They stated that female students are better than male students in China and they have a higher level of confidence in foreign language reading.

An important point must be taken into consideration is that there are many factors that affect the relationship between foreign language anxiety and gender. Among these factors are reading habit, the use of the strategies of learning, motivation, the students' beliefs concerning learning, and the level of proficiency. Green and Oxford (1995) investigated the relationship between gender and foreign language strategies and the result showed that females who are foreign language learners tend to use more strategies during the process of learning. Using more strategies from the side of the females shows that they can handle their feelings so that they can overcome the disturbance and feeling of anxiety which they experience during the process of learning.

The development of the anxiety which the students experience in the four skills has been investigated and the results showed that the development of the anxiety might be different between both genders.

Cambpell (1999) investigated the level of anxiety which the students experience two weeks before and after the beginning of the study. The result of the investigation before the beginning of the course showed that both males and females experience the same level of anxiety. However, the investigation which was carried out two weeks after the beginning of the course showed that the females experience lower level of anxiety than males. In this study, the percentage of the male students who experience reading anxiety rose $9 \%$ whereas the percentage of the female students who experience reading anxiety dropped $7 \%$ only after two weeks of the beginning of the course. The same study also found that the anxiety which the students experience in listening increased less than $1 \%$ among females and increased about 13\% among males.

Ezzi (2012) conducted her study in Yemen in Hodeidah University. The number of the participants is 163 students enrolled in the third and the fourth year. The data was collected using Foreign Language Classroom Anxiety Scale and the result shows that female students experience higher level of anxiety than male students. 
Another study is conducted by Kamarulzaman et al. (2013) in UKM, Malaysia to investigate anxiety among gifted learners. One of the aims was to investigate the difference in the level of anxiety between males and females. The result revealed that females experience higher level of anxiety than males.

\subsection{Foreign Language Anxiety and Academic Achievement}

The relationship between FLA and the performance of the students has been widely examined by many scholars who agreed that foreign language anxiety affects the students' performance negatively (MacIntyre \& Gardner 1991; Horwitz et al. 1986; Phillips 1992; Kamarulzaman et al. 2013).

Anxiety is a common phenomenon among EFL learners so the relationship between anxiety and the academic performance of the students has been investigated by many scholars (Aida 1994). The previous studies investigated the effect of anxiety on performance have shown mixed results such as Kleinmann (1977), Chastain (1975) and Young (1986). The study conducted by Chastain (1975) investigated the correlation between test anxiety and the performance among the students studying beginning courses in German, French and Spanish. The result showed that test anxiety has a positive correlation with the Spanish language, a negative correlation with the French language, and in terms of German language it was marginally positively correlated.

Kleinmann (1977) could find a positive relationship between the level of anxiety and the general use of avoided structures. There are several affective variables have a correlation with structure use which the participants avoided on the assessment task. However, these variables did not correlate with the use of the structures that the participants did not avoid. For the Arabic and Spanish speaking students of English language who seem to have anxiety were less likely to have avoidance for the structures that are complex such as passive voice and infinitive complements. Although the students avoided some complex structures, there are many variables related to the learners that motivate the students to produce such complex structures such as confidence and motivation. Young (1986) examined the relationship between anxiety and the performance of the students in foreign language oral test and she found that the level of anxiety does not have that effect on the performance of the students when they have a good level of proficiency. The participants in this study are sixty prospective teachers of Germany, Spanish and French. Young concluded that the oral performance is not influenced by anxiety when the effect of the individual's performance is taken into consideration by the learners. Also, she stated that the students were not anxious because the Oral Proficiency Interview is not an official test.

The results of the relationship between anxiety and performance are mixed and they have been discussed in different ways. According to Ellis (1994), investigating the relationship between the students' achievement and anxiety is not a linear one. In terms of the effect which anxiety has on performance, Alpert et al. (1960) have divided anxiety into debilitating anxiety and facilitating anxiety. Debilitating anxiety motivates the students to escape from the new learning tasks they encounter whereas the facilitating anxiety motivates the students to struggle when they encounter new learning takes. Williams (1991) discussed that these two types of anxiety might cancel each other and do not affect the performance of the students. He added that anxiety might have a facilitating function when the students experience a low level of anxiety whereas high level of anxiety results in debilitating function.

In addition, the difficulty of the task and the level of proficiency of the students influence the effect of anxiety on the students' performance. MacIntyre and Gardner (1991) supported this view as they found out that language anxiety did not have any effect on the English performance test but it had a negative effect on the French performance test. In other words, high level of anxiety is not related to easy tasks such as those given in the mother tongue but it is related to the difficult task especially when given in a second language as English.

Macintyre and Gardner (1989) found that the students who experience a higher level of communicative anxiety could remember fewer French words and learn slower than the other students. MacIntyre and Gardner (1991) found a negative relationship between the anxiety which the students experience and their performance on the test of French Categories and the test of Digit Span. Phillips (1992) used an oral test in order to examine the effect of anxiety on the students' performance. The result shows that the students with high level of anxiety tend to speak less, produce short sentences, and depend on independent clauses unlike the students who experience lower of level anxiety. About half of the students who study a second language experience debilitating language anxiety. Saito et al. (1996) argued that the level of the anxiety which the students experience in the beginner, intermediate and advanced level has a negative correlation with the grades which the students obtain in the exams. Kamarulzaman et al. (2013) investigated the correlation between anxiety and the performance among gifted learners in Malaysia and the result revealed that anxiety correlates negatively with gifted learners' performance.

In short, there are many studies that have investigated the relationship between the level of anxiety and the 
performance of the students and the results were mixed as the relationship between these two factors is to some extent complex. There are many factors that affect the performance such as the difficulty of the task and the level of anxiety (MacIntyre \& Gardner, 1991; Williams, 1991). There are other factors that lead to the mixed results in the relationship between anxiety and performance due to the unclear definition of FLA and the inconsistent of the measurements (MacIntyre \& Gardner, 1989). Besides, there were many efforts which have distinguished between the general anxiety and foreign language anxiety. Other studies have shown a consistent moderate negative relationship between anxiety and performance which have been measured by the test scores and the final grades of the students (Horwitz et al., 1986; Phillips, 1992; Aida, 1994).

\section{Study}

\subsection{Research Questions}

The study aims to answer the following questions:

1) What is the effect of gender on the level of anxiety among Yemeni university EFL students?

2) What is the relationship between the level of foreign language anxiety and the academic achievement of Yemeni university EFL students?

\subsection{Research Design}

This research is quantitative in nature since the data is collected through a questionnaire and the data is analysed by using SPSS version 22. Quantitative data collection has been used since it is the proper method to get temporary facts (Ebel, 1980).

\subsection{Participants}

The participants in this study are 155 students and this number is $20 \%$ of the overall number of the student in all levels in English Department, Faculty of Arts, Ibb University, Yemen. The method used in this study is stratified random sampling. The students have been divided to four groups according to year of study; level one, level two, level three and level four. Also, the students have been divided according to gender to males and females then $20 \%$ of the students have been taken from each level bearing in mind the number of males and females. Dividing the students into groups and using stratified random sampling in choosing the samples help to take samples equally from each group. Singh (2006) argues that it is typical to use 20 percent as samples from among the population in quantitative studies. The overall number of students is given in Table 1.

Table 1. Number of the students in English Department, Faculty of Arts, Ibb University

\begin{tabular}{llll}
\hline \multicolumn{4}{l}{ The number of the registered students at the Department of English, Faculty of Arts, Ibb University for the Year } \\
2014 & The number of the registered students \\
\hline Level & Males & Females & The sum \\
& 105 & 111 & 216 \\
One & 48 & 113 & 161 \\
Two & 74 & 100 & 174 \\
Three & 110 & 116 & 226 \\
Four & 337 & 440 & 777 \\
The overall number & & &
\end{tabular}

The number of the students who participated in this study is $20 \%$ of the overall number of the students as it is shown in Table 2. 
Table 2. Number of the students participated in the study

\begin{tabular}{llll}
\hline \multicolumn{4}{l}{ The number of the students participated in the study } \\
\hline Level & Males & Females & The sum \\
One & 21 & 22 & 43 \\
Two & 10 & 22 & 32 \\
Three & 15 & 20 & 35 \\
Four & 22 & 23 & 45 \\
The overall number & 68 & 87 & 155 \\
\hline
\end{tabular}

\subsection{Instrument}

This study used the Foreign language Anxiety Scale (FLAS) adopted from Yassin (2015) which aims to investigate the level of anxiety in the four skills. The students answered the items of the questionnaire and stated their gender and their university academic achievemet or CGP of the year 2014 for the sake of investigating the Effect of the level of anxity on gender and the academic achievement.

The questionnaire has 48 items adapted with modifications from three well-known anxiety scales which are Foreign Language Classroom Anxiety Scale (FLCAS) by Horwitz et al. (1986), Foreign Language Reading Anxiety (FLRA) developed by Saito et al. (1999) and Foreign Language Writing Anxiety Inventory (FLWAI) developed by Cheng (2004). The items that investigate the level of anxiety in speaking and listening are adapted from FLCAS and they are 13 items because they are related to speaking and listening. The items that investigate the level of anxiety in reading are adopted from FLRAS which include all the items. The items that investigate the level of anxiety in writing skill are adapted from FLWAI and they are 15 items only because Cheng (2004) stated that only 15 items fall directly in the three categories of writing anxiety which are Somatic Anxiety, Cognitive Anxiety and Avoidance Behavior, while the other items do not.

The study has adopted the FLAS because it investigates the level of anxiety in the four skills which gives the researcher a comprehensive overview about the level of anxiety which the students experience when they practice English language.

The scale has been revised by two professors for validity and it has a very good internal consistency as Cronbach's Alpha Validity of this scale is .807 . 


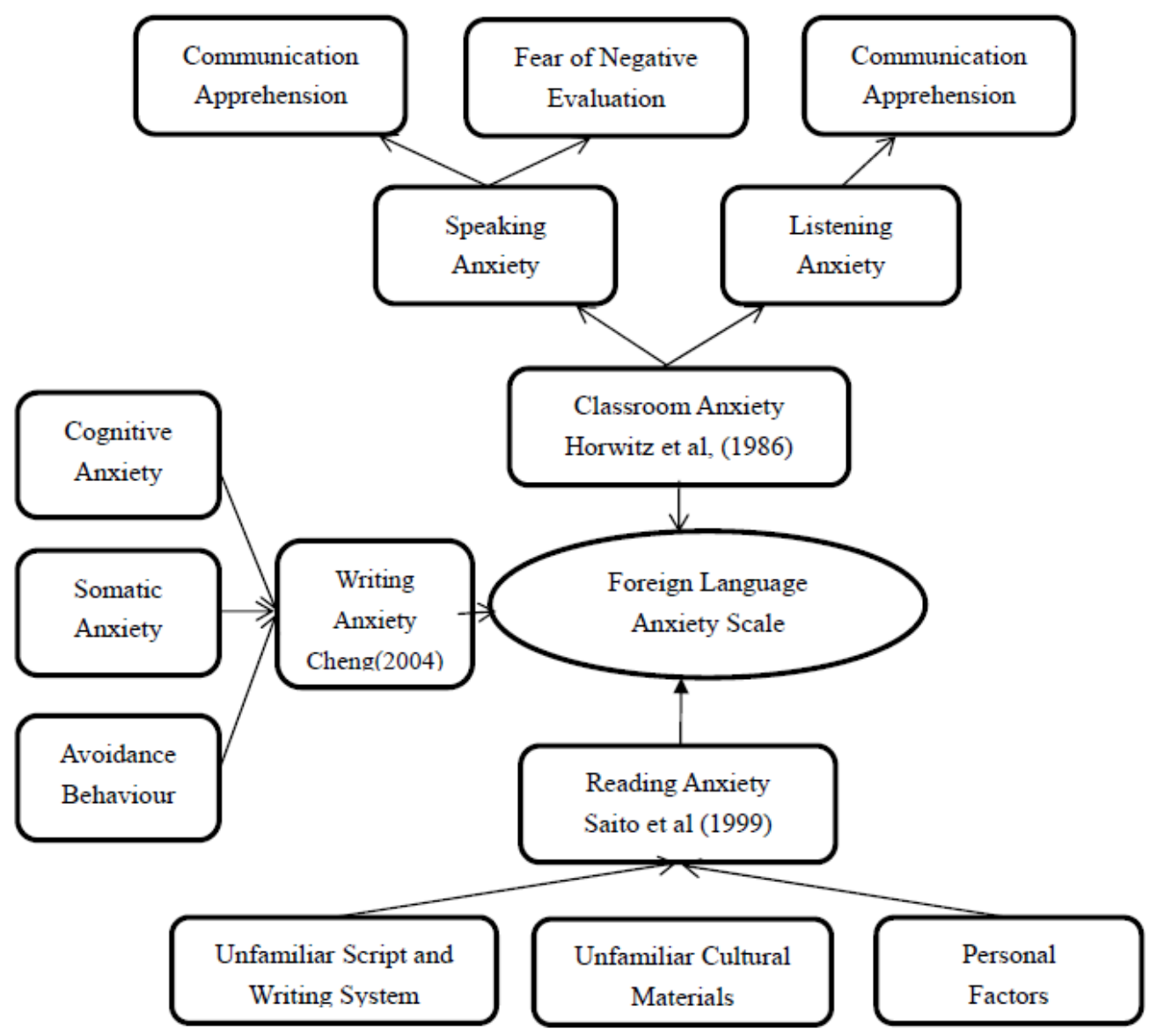

Figure 1. Foreign language anxiety scale

\subsection{Procedures}

The researchers took permission from the Head of English Department, Faculty of Arts, Ibb University, Yemen to collect the dats. Then the questionnaire was distributed to each level by teachers who do not teach the students in order to avoid any negative effect on the validity. The students were introduced to the questionnaire and its aims and were asked to write their first reaction which they get when reading the items in order to raise the level of honesty (Satio et al., 1999). The students were cooperative and all the students who participated in the study submit their copy to the teacher.

\subsection{Data Analysis}

The researcher used SPSS to analyze the data and the analysis is different in the two questions. In the first question which aims to investigate the differences between the students in the level of anxiety in terms of gender, the researcher used t-test. In the second question which aims to investigate the relationship between the foreign language anxiety and the academic achievement, Pearson Product-Moment Correlation is used between the overall level of anxiety and academic achievement.

\section{Results}

To find out if there is significant differences in the level of foreign language anxiety between male and female among Yemeni university EFL students, the researcher calculated the means and standard deviations of the male and female university students included in the sample which consist of (68) male and (87) female for the whole score of foreign language anxiety.

After that "independent samples t-test" was used to compare between the male and female in the level of foreign language anxiety. Table 3 clarifies the means, standard deviations and t-value of male and female students. 
Table 3. Means, standard deviations, T-Value and level of significance for the variable of gender

\begin{tabular}{llllllll}
\hline & Gender & No. & Mean & Std. Deviation & Df & t-value & Sig. (2-tailed) \\
\hline Total of & M & 68 & 135.735 & 19.0550 & 153 & -1.211 & 0.228 \\
Anxiety score & F & 87 & 139.782 & 21.7851 & & & \\
\hline
\end{tabular}

Table 3 shows that, the total anxiety mean value of male students is (135.735) and standard deviation is (19.055). The total anxiety mean value of female students is (139.782) and standard deviation is (21.785). The t-value is -1.211 and the significance level of $t$-value is 0.228 . Since the significance level of $t$-value 0.228 is greater than the significance level of 0.05 , it is inferred that there is no significant difference in the total foreign language anxiety scores between male and female Yemeni EFL university students with respect to gender.

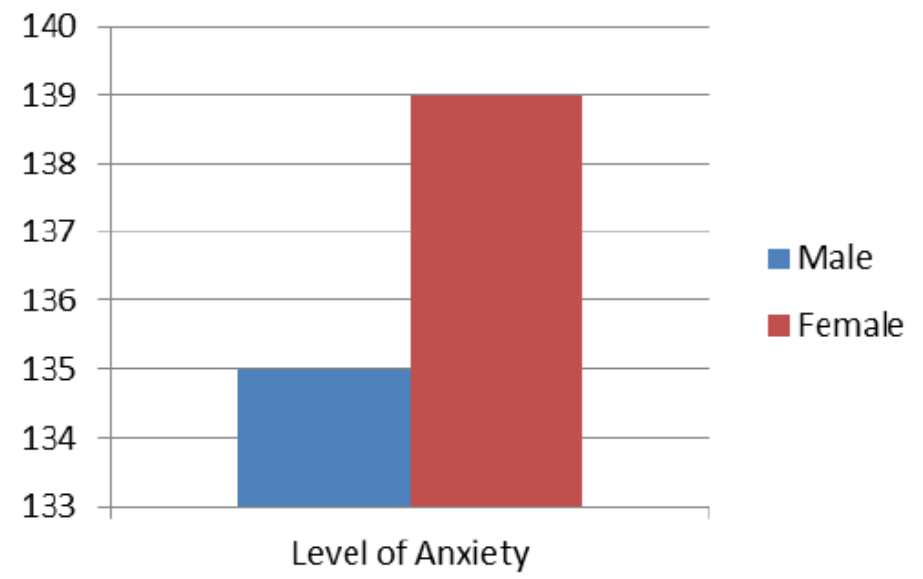

Figure 2. Level of anxiety among male and female students

To find out if there is correlation between the level of foreign language anxiety and the academic achievement of EFL Yemeni university students, the researcher used the Pearson Product-Moment Correlation. The correlation has been calculated between the academic achievement scores and foreign language anxiety scores. Table 4 clarifies the correlation between the level of foreign language anxiety and the academic achievement of Yemeni EFL university students.

Table 4. Correlation between the level of foreign language anxiety and the academic achievement of EFL Yemeni University students

\begin{tabular}{llll}
\hline Source of correlation & N & Pearson Correlation & Sig. (2-tailed) \\
\hline Total of Anxiety score & 155 & -0.103 & $\mathbf{0 . 2 0 4}$ \\
$\mathrm{X}$ & & & \\
Academic Achievement score & & & \\
\hline
\end{tabular}

From the Table 4 it is observed that there is no significant relation between the academic achievement and level of foreign language anxiety scores.

\section{Discussion}

A. What is the difference in the level of anxiety between the students according to gender?

This study question investigates if there is a significant difference in the level of anxiety between male and female students. The result shows that the female students experience a higher level of anxiety than the male students but the f-value shows that the difference is not significant.

There are many studies that have investigated this issue and the results showed that the relationship between foreign language anxiety and gender is a controversial matter. In the case of Yemeni students, the difference 
between male and female students is not that high may be because the number of the female students in the department is more than the male students as the number of the male students is 337 and the number of the female students is 440 . The majority of the females might give them the freedom to act naturally inside the classroom which in return lowers the level of anxiety and compensate for the shy nature of the females. Also, both genders have studied English as a foreign language for many years before their attendance at the university which might be the reason for not finding a significant difference between both genders. The females anxiety mean was a little bit higher than the anxiety mean of the male students because they are shy in nature and studied separately from males from the first to the twelfth grade.

A study conducted among Yemeni university students by Ezzi (2012) found that there is a significant difference between males and females. However, the number of the females in this study is 151 students and the number of males is 12 students only. This might affect the measure of the difference between both genders as female students outnumber male students. On the other hand, in this paper there is no significant difference between both genders and the result is accepted because the number of the males who participated in this thesis is 68 and the number of females is 87 and this number is $20 \%$ of the whole number of the students.

Abu-Rabia (2004) has investigated the level of anxiety among both males and females who are studying in the seventh grade in Israel. The participants are taken from two different classes who are studying English as a foreign language. The result shows that the female students experience higher level of anxiety than male students and the difference is significant. The result is different from the result obtained from the Yemeni students as the difference between male and female students is not significant. This might be due to the difference between the students in terms of age because the students in the study of Abu-Rabia are still in the seventh grade whereas the students in this study are undergraduate university students. The difference in age might give the female Yemeni students the priority since they have studied English for many years and the experience of the secondary school might reduce the level of anxiety which the students experience when learning a foreign language.

Moreover, Ekin Ergun (2011) investigated the correlation between foreign language anxiety and gender at Attlim University Preparatory School in Turkey. The result of this study revealed that female students experience higher level of anxiety than male students. The researcher argues that the families have an effect on their children in terms of their success as they demand too much from their children which has an effect on their study. He argues that when the children feel the responsibility under the pressure of their families, they might feel nervous and females are more submissive to the pressure because they are more dependent on their families than males. This is different from the case of the majority of Yemeni students as both males and females are dependent on their families during the years of their attendance at the university. Looking at the issue from this point of view, the result of this study which did not find a significant difference between male and female Yemeni students is logical because females as well as males are under the same pressure of responsibility.

However, Aida (1994) did not find a significant foreign language classroom anxiety difference between males and females among Japanese students. Also, Shi and Liu (2006) found that there is no significant difference between males and females among Chinese EFL learners in terms of anxiety. The results of these two studies seem to be similar to the result obtained from Yemeni students in this study. The result obtained from Yemeni students is the same as there is no significant difference between the male and female students and the reason seems to be that both Yemeni students as well as Japanese and Chinese students have a completely different writing system form English language. This might raise the level of anxiety and make it similar between males and females because both genders are not familiar with the English writing system. When the students come across a new writing system and unfamiliar letters and words, they feel anxious and this situation is experienced by both males and females. Another reason might be that the English culture is completely different from the Yemeni, Japanese, and Chinese culture and both genders are living in countries which have different traditions and values which affects all the students regardless of their gender. Every culture has its own ways of greetings, requesting, traditions, and values which are reflected in the language and the topics discussed by the students. It seems that the Yemeni students as well as the Japanese and Chinese students have the same experience in this regard both males and females which in turn raise the level of anxiety equally among the students.

B. What is the relationship between the foreign language anxiety and the academic achievement among Yemeni university EFL students?

The second question investigates the correlation between the foreign language anxiety and the academic achievement of the students which has been investigated through their academic scores of the first semester.

The result of the analysis shows that there is no significant correlation between the level of anxiety and the academic achievement as the result is $(\mathrm{r}=-0.103, \mathrm{n}=155)$. Also, there is no significant correlation between the 
four skills and the academic achievement of the students.

There is no significant relationship between the level of anxiety and the academic achievement of the students because the relationship between the results of both anxiety and the academic achievement are not consistent. The reason that stands behind this might be due to the fact that the students in level one and two do not study English language courses only as they study Arabic language in the two semesters. Students in level one study subjects in Arabic language such as Islamic culture, Arabic language, Windows and Microsoft Word which makes it easier for the students to understand their teachers and also might influence the results of the students. Besides, students in level three and level four have gained enough experience to deal with exams. So, there is no significant negative relationship between the level of anxiety and the academic achievement of the students even if the students move from one level to another.

There are many studies investigated the correlation between the level of anxiety and the academic achievement of the students and the results of some of the studies have found a negative correlation between the level of anxiety and the academic achievement of the students.

Horwitz et al. (1986) investigated the correlation between the level of anxiety and the final grades of the students who are studying Japanese, Spanish and French languages. The results of the study show that there is a negative correlation between the level of anxiety and the final grades of the students as those who experience a high level of anxiety tend to get low marks in the exams. Also, Abu-Ghararah (1999) Batumlu and Erden (2007) have found the same result.

However, some studies showed mixed results as the level of anxiety might not affect the academic achievement of the students. Chastain (1975) investigated the correlation between test anxiety and the performance among the students studying beginning courses in German, French and Spanish. The result showed that test anxiety has a positive correlation with the Spanish language, has a negative correlation with the French language, and in terms of German language it was marginally positively correlated.

The result of this study showed no correlation between the level of anxiety and the academic achievement of the students and this might be due to the fact that the Yemeni university EFL students study some courses in Arabic language which makes it easier for the students to understand their teachers and answer the exam questions in a better way since they use the mother tongue instead of the target language in writing the answers of some courses in the first and second level. This is supported by MacIntyre and Gardner (1991) who argued that the effect of anxiety on the academic performance might appear when the students receive the tasks in the target language but not when the students receive the tasks in the mother tongue.

Alpert et al. (1960) have divided anxiety into debilitating anxiety and facilitating anxiety. Debilitating anxiety motivates the students to escape from the new learning tasks they encounter whereas the facilitating anxiety motivates the students to struggle when they encounter new learning tasks. Williams (1991) discussed that these two types of anxiety might cancel each other and do not affect the performance of the students. This might be an explanation why there is no relationship between the level of anxiety and the academic achievement in the case of Yemeni students which supports Ellis (1994) who stated that investigating the relationship between the students' achievement and anxiety is not a linear one.

\section{Conclusion}

The study aimed at investigating the gender differences in the level of anxiety among Yemeni university EFL students. The second question of the study aimed to investigate the relationship between the level of anxiety and the academic achievement of the students. The result of the first question showed that there is no significant difference between both genders although the level of anxiety of the females was higher than that of the male students. The result of the second question showed that there is no significant correlation between the level of anxiety and the academic achievement of the students. However, the level of anxiety declines when the students moves from lower levels to the higher levels. Also, subjects taught in first language have an effect on the relationship between anxiety and academic achievement as the students who study courses in the mother tongue might experience lower level of anxiety than those who study all the courses in the target language which also leads to slight effect on the academic achievement. This study supports the idea that the relationship between foreign language anxiety and gender is a controversioal matter and it is different from one situation to another. Also, it supports the idea that the relationship between foreign language anxiety and academic achievement is nonlinear.

\section{References}

Abu-Ghararah, A. H. (1999). Learning Anxiety and English Language Achievement of Male and Female 
Students of University and Secondary Stages in Al-Madinah Al-Munawwarah; A Comparative Research Study. King Abdulaziz University Journal, 12(1), 3-29. http://dx.doi.org/10.4197/Edu.12-1.2

Aida, Y. (1994). Examination of Horwitz, Horwitz, and Cope's construct of foreign language anxiety: The case of students of Japanese. The modern language journal, 78(2), 155-168. http://dx.doi.org/10.1111/j.1540-4781.1994.tb02026.x

Alpert, R., \& Harper, R. (1960). Anxiety in academic achievement situation. Journal of Abnormal and Social Psychology, 61(2), 207-215. http://dx.doi.org/10.1037/h0045464

Bailey, K. (1983). Competitiveness and anxiety in adult second language leaning: Looking at and through the diary studies. In H. Seliger, \& M. Long (Eds.). Classroom-oriented research in second language acquisition (pp. 67-102). Rowley: Mass Newbury House.

Batumlu, D. Z., \& Erden, M. (2007). The relationship between foreign language anxiety and English achievement of Yildiz technical university school of foreign languages preparatory students. Journal of theory and practice in education, 3(1), 24-38.

Bensoussan, M., \& Zeidner, M. (1989). Anxiety and achievement in a multicultural situation. Assessment in Higher Education, 14(1), 40-54. http://dx.doi.org/10.1080/0260293890140105

Campbell, C. M. (1999). Language anxiety in men and women: Dealing with gender difference in the language classroom. Affect in foreign language and second language learning: A practical guide to creating a low anxiety classroom atmosphere (pp. 191-215).

Chastain, K. (1975). Affective and ability factors in second language acquisition. Language Learning, 25(1), 153-161. http://dx.doi.org/10.1111/j.1467-1770.1975.tb00115.x

Cheng, Y. S. (2004). A measure of second language writing anxiety: Scale development and preliminary validation. Journal of Second Language Writing, 13(4), 313-335. http://dx.doi.org/10.1016/j.jslw.2004.07.001

Comunian, A. L. (1993). Anxiety, cognitive interference, and school performance of Italian children. Psychological reports, 73(3), 747-754. http://dx.doi.org/10.2466/pr0.1993.73.3.747

Ebel, R. L. (1980). Survey research in education: The need and the value. Peabody Journal of Education, 57(2), 126-134. http://dx.doi.org/10.1080/01619568009538278

Ellis, R. (1994). The study of second language acquisition. Oxford: Oxford University Press.

Ergun, E. (2011). An Investigation Into the Relationship Between Emotional Intelligence and Foreign Language Anxiety of Students at a Private University. Unpublished MA Thesis, Middle East Technical University, Turkey.

Ezzi, N. A. A. (2012). The impact of gender on the foreign language anxiety of the Yemeni university students. International Journal of Applied Linguistics \& English Literature, 1(2), 65-75. http://dx.doi.org/10.7575/ijalel.v.1n.2p.65

Green, J. M., \& Oxford, R. (1995). A closer look at learning strategies, L2 proficiency, and gender. TESOL Quarterly, 29(2), 261-297. http://dx.doi.org/10.2307/3587625

Horwitz, E. K., Horwitz, M. B., \& Cope, J. (1986). Foreign language classroom anxiety. The Modern language journal, 70(2), 125-132. http://dx.doi.org/10.1111/j.1540-4781.1986.tb05256.x

Kamarulzaman, M. H., Ibrahim, N., Yunus, M. M., \& Ishak, N. M. (2013). Language anxiety among gifted learners in Malaysia. English Language Teaching, 6(3), 20-29. http://dx.doi.org/10.5539/elt.v6n3p20

Kleinmann, H. (1977). Avoidance behavior in adult second language acquisition. Language learning, 27(1), 93-107. http://dx.doi.org/10.1111/j.1467-1770.1977.tb00294.x

MacIntyre, P. D., \& Gardner, R. C. (1989). Anxiety and Second - Language Learning: Toward a Theoretical Clarification. Language learning, 39(2), 251-275. http://dx.doi.org/10.1111/j.1467-1770.1989.tb00423.x

MacIntyre, P. D., \& Gardner, R. C. (1991). Methods and Results in the Study of Anxiety and Language Learning: A Review of the Literature*. Language learning, 41(1), 85-117. http://dx.doi.org/10.1111/j.1467-1770.1991.tb00691.x

Mwamwenda, T. S. (1994). Test anxiety and academic achievement among South African university students. Psychological reports, 75(3f), 1593-1594. http://dx.doi.org/10.2466/pr0.1994.75.3f.1593 
Phillips, E. M. (1992). The effects of language anxiety on students' oral test performance and attitudes. The modern language journal, 76(1), 14-26. http://dx.doi.org/10.1111/j.1540-4781.1992.tb02573.x

Saito, Y., \& Samimy, K. K. (1996). Foreign language anxiety and language performance: A study of learner anxiety in beginning, intermediate, and advanced - level college students of Japanese. Foreign Language Annals, 29(2), 239-249. http://dx.doi.org/10.1111/j.1944-9720.1996.tb02330.x

Shi, Y. Z., \& LIU, Z. Q. (2006). Foreign Language Reading Anxiety and Its Relationship to English Achievement and Gender. Journal of Pla University of Foreign Languages, 29, 59-65.

Spielberger, C. D. (1983). Manual for the state-trait anxiety inventory (form Y). Palo Alto, California: Consulting Psychologists Press.

Tanveer, M. (2007). Investigation of the factors that cause language anxiety for ESL/EFL learners in learning speaking skills and the influence it casts on communication in the target language. Unpublished doctoral dissertation. University of Glasgow.

Williams, K. (1991). Anxiety and formal second/foreign language learning. RELC Journal, 22(2), 19-28. http://dx.doi.org/10.1177/003368829102200202

Yassin, A. A. (2015). Investigating Foreign Language Anxiety Among Yemeni University EFL Students. Unpublished MA Thesis: UKM, Malaysia.

Young, D. J. (1986). The relationship between anxiety and foreign language oral proficiency ratings. Foreign Language Annals, 19(5), 439-445. http://dx.doi.org/10.1111/j.1944-9720.1986.tb01032.x

\section{Appendix}

\section{Foreign Language Anxiety Scale}

Directions: Statements 1 through 48 refers to how you feel about English when you read, write, or communicate with others. For each statement, please indicate whether you (1) strongly disagree, (2) disagree, (3) neither agree nor disagree, (4) agree, or (5) strongly agree by marking the appropriate number on the line following each statement. Please give your first reaction to each statement and mark one answer for each statement.

SD $=$ Strongly Disagree, $\mathbf{D}=$ Disagree, $\mathbf{N}=$ Neutral, $\mathbf{A}=$ Agree, $\mathbf{S A}=$ Strongly Agree

\section{Gender: Male $\square$ Female}

Your accumulative grade of the first semester:

\begin{tabular}{|l|l|l|l|l|l|l|}
\hline NO. & Questions & SD & D & N & A & SA \\
\hline 1 & $\begin{array}{l}\text { I never feel quite sure of myself when I am speaking in a foreign } \\
\text { language. }\end{array}$ & 1 & 2 & 3 & 4 & 5 \\
\hline 2 & $\begin{array}{l}\text { I start to panic when I have to speak without preparation in a foreign } \\
\text { language. }\end{array}$ & 1 & 2 & 3 & 4 & 5 \\
\hline 3 & $\begin{array}{l}\text { It embarrasses me to volunteer answers in my language class. } \\
\text { *I would not be nervous speaking the foreign language with native } \\
\text { speakers. }\end{array}$ & 1 & 2 & 3 & 4 & 5 \\
\hline 4 & *I feel confident when I speak in foreign language. & 1 & 2 & 3 & 4 & 5 \\
\hline 5 & $\begin{array}{l}\text { I am afraid that my language teacher is ready to correct every mistake } \\
\text { I make. }\end{array}$ & 1 & 2 & 3 & 4 & 5 \\
\hline 7 & $\begin{array}{l}\text { I feel very self-conscious about speaking the foreign language in front } \\
\text { of others. }\end{array}$ & 1 & 2 & 3 & 4 & 5 \\
\hline 8 & $\begin{array}{l}\text { I get nervous and confused when I am speaking in English. } \\
\text { I feel overwhelmed by the number of rules I have to learn to speak a } \\
\text { foreign language. }\end{array}$ & 1 & 2 & 3 & 4 & 5 \\
\hline 9 & $\begin{array}{l}\text { I am afraid that the other students will laugh at me when I speak the } \\
\text { foreign language. }\end{array}$ & 1 & 2 & 3 & 4 & 5 \\
\hline 10 & 2 & 3 & 5 \\
\hline
\end{tabular}




\begin{tabular}{|c|c|c|c|c|c|c|}
\hline 11 & $\begin{array}{l}\text { It frightens me when I don't understand what the teacher is saying in } \\
\text { the foreign language. }\end{array}$ & 1 & 2 & 3 & 4 & 5 \\
\hline 12 & I get upset when I don't understand what the teacher is correcting. & 1 & 2 & 3 & 4 & 5 \\
\hline 13 & $\begin{array}{l}\text { I get nervous when I don't understand every word the other person } \\
\text { says in English. }\end{array}$ & 1 & 2 & 3 & 4 & 5 \\
\hline 14 & $\begin{array}{l}\text { I get upset when I am not sure whether I understand what I am } \\
\text { reading in English }\end{array}$ & 1 & 2 & 3 & 4 & 5 \\
\hline 15 & $\begin{array}{l}\text { When reading English, I often understand the words but still can't } \\
\text { quite understand what the author is saying. }\end{array}$ & 1 & 2 & 3 & 4 & 5 \\
\hline 16 & $\begin{array}{l}\text { I feel intimidated whenever I see a whole page of English in front of } \\
\text { me. }\end{array}$ & 1 & 2 & 3 & 4 & 5 \\
\hline 17 & $\begin{array}{l}\text { I am nervous when I am reading a passage in English when I am not } \\
\text { familiar with the topic. }\end{array}$ & 1 & 2 & 3 & 4 & 5 \\
\hline 18 & $\begin{array}{l}\text { I get upset whenever I encounter unknown grammar when reading } \\
\text { English. }\end{array}$ & 1 & 2 & 3 & 4 & 5 \\
\hline 19 & $\begin{array}{l}\text { When reading English, I get nervous and confused when I don't } \\
\text { understand every word. }\end{array}$ & 1 & 2 & 3 & 4 & 5 \\
\hline 20 & $\begin{array}{l}\text { It bothers me to encounter words I can't pronounce while reading } \\
\text { English. }\end{array}$ & 1 & 2 & 3 & 4 & 5 \\
\hline 21 & $\begin{array}{l}\text { By the time you get past the funny letters and symbols in English, it's } \\
\text { hard to remember what you're reading about. }\end{array}$ & 1 & 2 & 3 & 4 & 5 \\
\hline 22 & I usually end up translating word by word when I'm reading English. & 1 & 2 & 3 & 4 & 5 \\
\hline 23 & $\begin{array}{l}\text { I am worried about all the new symbols you [I] have to learn in order } \\
\text { to read English. }\end{array}$ & 1 & 2 & 3 & 4 & 5 \\
\hline 24 & English culture and ideas seem very foreign to me. & 1 & 2 & 3 & 4 & 5 \\
\hline 25 & $\begin{array}{l}\text { You have to know so much about English history and culture in order } \\
\text { to read English. }\end{array}$ & 1 & 2 & 3 & 4 & 5 \\
\hline 26 & $\begin{array}{l}\text { When I'm reading English, I get so confused I can't remember what } \\
\text { I'm reading. }\end{array}$ & 1 & 2 & 3 & 4 & 5 \\
\hline 27 & *I enjoy reading English. & 1 & 2 & 3 & 4 & 5 \\
\hline 28 & *I feel confident when I am reading in English. & 1 & 2 & 3 & 4 & 5 \\
\hline 29 & *Once you get used to it, reading English is not so difficult. & 1 & 2 & 3 & 4 & 5 \\
\hline 30 & The hardest part of learning English is learning to read. & 1 & 2 & 3 & 4 & 5 \\
\hline 31 & $\begin{array}{l}\text { I would be happy just to learn to speak English rather than having to } \\
\text { learn to read as well. }\end{array}$ & 1 & 2 & 3 & 4 & 5 \\
\hline 32 & $\begin{array}{l}\text { I don't mind reading to myself, but I feel very uncomfortable when I } \\
\text { have to read English aloud. }\end{array}$ & 1 & 2 & 3 & 4 & 5 \\
\hline 33 & $\begin{array}{l}\text { *I am satisfied with the level of reading ability in English that I have } \\
\text { achieved so far. }\end{array}$ & 1 & 2 & 3 & 4 & 5 \\
\hline 34 & I feel my heart pounding when I write English. & 1 & 2 & 3 & 4 & 5 \\
\hline 35 & $\begin{array}{l}\text { My mind often goes blank when I start to work on an English } \\
\text { composition. }\end{array}$ & 1 & 2 & 3 & 4 & 5 \\
\hline 36 & $\begin{array}{l}\text { I tremble or perspire when I write English compositions under time } \\
\text { pressure. }\end{array}$ & 1 & 2 & 3 & 4 & 5 \\
\hline 37 & $\begin{array}{l}\text { My thoughts become jumbled when I write English compositions } \\
\text { under time constraint. }\end{array}$ & 1 & 2 & 3 & 4 & 5 \\
\hline
\end{tabular}




\begin{tabular}{|l|l|l|l|l|l|l|}
\hline 38 & $\begin{array}{l}\text { I often feel panic when I write English compositions under time } \\
\text { constraint. }\end{array}$ & 1 & 2 & 3 & 4 & 5 \\
\hline 39 & I freeze up when unexpectedly asked to write English compositions & 1 & 2 & 3 & 4 & 5 \\
\hline 40 & $\begin{array}{l}\text { I usually feel my whole body rigid and tense when I write English } \\
\text { compositions. }\end{array}$ & 1 & 2 & 3 & 4 & 5 \\
\hline 41 & *I often choose to write down my thoughts in English. & 1 & 2 & 3 & 4 & 5 \\
\hline 42 & $\begin{array}{l}\text { *I usually seek every possible chance to write English compositions } \\
\text { outside of class. }\end{array}$ & 1 & 2 & 3 & 4 & 5 \\
\hline 43 & *Whenever possible, I would use English to write compositions. & 1 & 2 & 3 & 4 & 5 \\
\hline 44 & $\begin{array}{l}* I \text { don't worry that my English compositions are a lot worse than } \\
\text { others'. }\end{array}$ & 1 & 2 & 3 & 4 & 5 \\
\hline 45 & $\begin{array}{l}\text { I'm afraid that the other students would deride my English } \\
\text { composition if they read it. }\end{array}$ & 1 & 2 & 3 & 4 & 5 \\
\hline 46 & $\begin{array}{l}* \text { I don't worry at all about what other people would think of my } \\
\text { English compositions. }\end{array}$ & 1 & 2 & 3 & 4 & 5 \\
\hline 47 & $\begin{array}{l}\text { I'm afraid of my English composition being chosen as a sample for } \\
\text { discussion in class. }\end{array}$ & 1 & 2 & 3 & 4 & 5 \\
\hline 48 & $\begin{array}{l}* \text { I'm not afraid at all that my English compositions would be rated as } \\
\text { very poor. }\end{array}$ & 1 & 2 & 3 & 4 & 5 \\
\hline
\end{tabular}

*These Items are positive so the scores should be reversed.

\section{Copyrights}

Copyright for this article is retained by the author(s), with first publication rights granted to the journal.

This is an open-access article distributed under the terms and conditions of the Creative Commons Attribution license (http://creativecommons.org/licenses/by/4.0/). 